\title{
АРХИВ
}

\section{Материалы обследования кафедры китайского языка ДВГУ, декабрь 1935 - январь 1936 годов. Часть 3}

\author{
DOI https://doi.org/10.24866/2542-1611/2021-3/137-154
}

Знак «"» в тексте источника заменён на знак «ъ»; исправления, внесённые в текст сразу после его написания, включены в публикацию. Исправлены однозначные опечатки и изъяты избыточные знаки препинания. Сохранён авторский грамматический стиль и способ написания слов. Все редакторские пометки и исправления помещены в квадратные скобки [ ]. Документы имеют перекрёстные ссылки, поэтому в части материалов проставлена оригинальная пагинация страниц в угловых скобках $<>$ в месте начала каждой страницы за исключением первой.

№ 8

\section{ДЕКАНУ ВОСФАК`А.}

Представляя составленный мною «Критический обзор материалов обследования кафедры китайского языка», считаю нужным сообщить, что кафедра китайского языка, приходя к противоположным, чем обследование, выводам относительно настоящего положения кафедры, находит, наоборот, целый ряд неправильностей и искажений, допущенных обследованием т. Феклина.

Тем не менее, допуская вполне естественное существование слабых мест в работе кафедры (во всяком случае не тех, которые указываются обследованием), члены кафедры в процессе своей дальнейшей работы, как и ранее, будут неуклонно стремиться к изжитию темных сторон ее деятельности и всемерному развитию как учебного режима так и научно-исследовательской работы.

В виду этого кафедра в конце «критического обзора» выдвигает ряд пожеланий, осуществление которых она признает необходимым в течение весеннего семестра 1936 г.

Приложение. Критический обзор материалов обследования кафедры китайского языка.

Заведующий кафедрой кит. яз. Проф. А. Рудаков 9/II 36
Публикацию подготовил: Барбенко Ярослав Александрович, канд. ист. наук, доцент кафедры политологии Восточного института - Школы региональных и международных исследований, ДВФУ (г. Владивосток). Электронная почта: prohist@ya.ru

Продолжение. Начало см.: Известия Восточного инсти тута. 2021. № 1. С. 89-113; Известия Восточного инсти тута. 2021. № 2. С. 129-146.
Для иитирования:

Материалы обследования кафедры китайского языка ДВГУ, декабрь 1935 - январь 1936 учебного года. Часть 3 // Известия Восточного института. 2021. № 3. C. 137-154. DOI https://doi. org/10.24866/2542-1611/20213/137-154 
1 Документ № 1.

ПРОФ. А. В. РУДАКОВ

\title{
КРИТИЧЕСКИЙ ОБЗОР МАТЕРИАЛОВ ПО ИТОГАМ ОБСЛЕДО- ВАНИЯ РАБОТЫ КАФЕДРЫ КИТАЙСКОГО ЯЗЫКА ВОСТОЧНО- ГО ФАКУЛЬТЕТА Д. В. Г. У.
}

\author{
Эпиграф. \\ Конфуций сказал: - Ю, научить ли тебя знанию? \\ Что знаешь, то и говори, что знаешь; \\ а чего не знаешь, то и говори, что не знаешь. \\ Это и есть знание.
}

Лунь-юй.

Результатом обследования кафедры китайского языка бригадой, состоявшей из преп. японского языка т. Феклина и студенческих представителей: т. т. Потапова и Денищенко, во второй половине декабря 1935 года, явилась докладная записка ${ }^{1}$ по вышеозначенным заглавием, подписанная научным работником К. Феклиным 31/XII, Владивосток.

Данные «материалы» начинаются с: - 1. Наличие программ по отдельным языковым дисциплинам и т. д. - Констатируется десять программ плюс учебный план, к которым дается общая характеристика и несколько коротких реплик по содержанию той или другой программы.

Мы, со своей стороны, не можем не обратить должного внимания на следующие пункты.

Относительно 6-го пункта: - Учебная программа по китайскому газетно-журнальному стилю для 2, 3 и 4 курсов» - подается такая реплика: ...« - сводная записка, без хотя бы схематического пояснения номенклатуры даваемого грамматического материала...» - Скажем, что ясная целеустановка этого курса сделана в семи строках введения к нему. Затем, вследствие того, что 1) имеется специальная программа по основам литературного языка для III курса и 2) программа по грамматике доцента т. Червонецкого (по разговорному языку, а след. - и по байхуа), то кафедра кит. яз. Не находит нужным перегружать все специальные программы еще общим грамматическим материалом. (Не наблюдается такая перегрузка и в программах по кит. яз. Московского института востоковедения имени Нариманова и лингвистического факультета ленинградского гос. института ист. философии и лингвистики).

Относительно 9-го пункта: - «Учебная программа по истории кит. литературы...» и т. д. необходимо отметить, что она первоначально предполагалась для IV курса, но затем по предположениям деканата решено было на IV курсе ее не проходить. Но затем, после спешной перестройки, - так сказать, на ходу, - планов преподавания на V курсе, мною была составлена другая программа преподавания этого предмета, имеющая главным образом языковую основу, на которой развились два противоположные разветвления стилей китайского языка, именно: 1) вэньли или чисто литературный на основе древних конфуцианских и даосских классических книг и 2) байхуа или современный разговорный. Эти основные положения курса изложены мною в учебном плане для V курса кит. отд. Восфака на 35/36 ак. г., 
препровожденном в деканат 27/IX 35 г. Об этом курсе я еще буду говорить ниже,когда придется коснуться о неправильном освещении его, сделанном одним из студ. представителем, очевидно - Денищенко.

По пункту 10-му. - «Учебная программа по кит. классическому лит. яз.» и т. д. Отмечено т. Феклиным: - чрезвычайно сжатый материал - 9 строчек. На самом деле программы по двум предметам занимают $2 / 3$ страницы. Если даже относить данную реплику только к официально-деловому стилю, то нельзя не сказать, что сжатость и лаконичность программ такого рода вообще является непременным требованием для составления их. Это особенно наблюдается в программах двух перечисленных научных учреждениях Москвы и Ленинграда, - программах, утвержденных Наркомпросом. Так, в программе Наримановского института по кит. яз. - обзор материала по оффициальному языку помещается в четырех строках, причем <стр. 2> цельная программа по языку ничего не теряет от этого в смысле общего охвата всего предмета.

Кроме перечисленных в «материалах» программ кит. кафедры, мною было своевременно препровождены в деканат и учебный отдел - имеется у меня в копиях (на пишущей машинке через копировальную бумагу) производственный план кафедры, помеченный 19/ IX 35 г., и два рабочих плана, один от 29/VIII 35 г. и другой, детально развернутый календарный план от 5/IX 35 г. Кроме этого имеется специальный план точного распределения числа часов с распределением поручений, рассмотренный и утвержденный в заседании кафедры 4 июня прошлого [1935] года. От такого плана требуется точность и наглядность, что пунктуально и выполнено. Какие либо дополнительные объяснения были признаны излишними. Если к этому перечислению прибавить два подробные «задания»по производственной практике, составленные Червонецким и Рудаковым, и протоколы заседаний кафедры китайского языка, то получится весьма обстоятельный материал по изучению работы кафедры.

Останавливаясь на наших программах, необходимо отметить, что т. Чжаном представлялись к заседаниям кафедры программы его заданий на китайском языке, которым давался дальнейший ход. Неверно заявление обследования, что «сериозным отрицательным моментом... является полное игнорирование работы преподавателя-национала по разговорному языку. Никаких методических указаний или хотя бы наметок преподавателю не дается...» (стр. 2). В протоколах заседаний кафедры имеются неоднократные методические указания и наметки практической работы т. Чжана со студентами. Если обследование не имело всех протоколов, или не желало ознакомиться с ними, то оно хотя бы обратилось за справками к бывшим секретарям заседаний кафедры, напр. к т. Поповой.

Последний абзац 1 статьи «материалов» не выдерживает и самой снисходительной критики. Наивно звучит высказывание: «...курьезно выглядит фраза в прогр. V курса: приобретение навыков в пользовании словарями на китайском языке...» и т. д. Но дело в том, что речь идет о таких словарях для китайцев, как цыюань, кансидянь, пэйвэнь юньфу, гуанюнь и др. Ключи в китайских словарях (первых двух) не расположены по нашей общепринятой в синологии нумерации с присвоением определенного № каждому ключу, но по особой системе циклических знаков. Объяснения иероглифов делаются на литератур- 
ном языке, о котором наши студенты IV, а в особенности III курса, имеют лишь общее представление. Преждевременная работа с этими словарями, - кроме большой затраты времени и сомнительности того, правильно ли понято значение иероглифа, данного на литературном языке с цитатами из многих неизвестных студентам кит. сочинений, явится совершенно бесполезной, так как повлечет за собою грубые, недопустимые ошибки. Для начинающих изучать язык работа с рифмическими словарями невероятно сложна, ибо требует специальных знаний по фонетике китайского литературного языка в ее исторической перспективе, и по меньшей мере было бы странно преждевременно взваливать на III и IV курсы такую непосильную ношу. Прежде чем легкомысленно судить о таких сложных предметах, как цыюань, кансицзыдянь или пэйвэньюньфу, обследованию полезно было бы проштудировать предисловие на кит. к словарю: кансицзыдянь или для суждения о пэйвэньюньфу просмотреть «Фонологию» Кальгрена в 4-х томах, чтобы быть скромнее в своих выступлениях.

В заключение обзора материалов по кафедре китайского языка необходимо еще упомянуть о разработке проблем методики преподавания китайского языка. Так, доцентом т. Червонецким составлена записка: «О преподавании кит. яз. на вос. фак. ДВГУ», помеченная:Влад. 25/III 34 г. (14 стр.), и кроме того, - на основании резолюции первой московской областной производственной конференции преподавателей иноязыков (14/IV-32 г.) - проф. Рудаковым составлена записка: «О новом учебнике китайского разговорного языка» (опыт методической установки) (13 стр.), как отразившем в себе основы марксистсколенинской лингвистики. Независимо от сего, <стр. 3> методика преподавания кит. яз. в средних школах нашего ДВК также была в поле зрения научных работников Рудакова и Червонецкого. По предложению директора ДВГУ ими разработана подробная докладная записка по этому предмету, которая в свое время была сообщена высшим инстанциям края по народному образованию. Те детали преподавания языка, которые с такой самостоятельностью были разработаны для каждой группы средней школы с наметками соответственных учебных планов и программ, - являются красноречивым доказательством того, что означенные научные работники со всесторонней отчетливостью представляют себе, как нужно преподавать китайский язык и в средней школе и в высшей, и только надо удивляться нашим студенческим представителям, с какой легкостью они берутся за выводы вроде следующих: «...методы преподавания кит. яз (деловой газетный стиль)... не на высоте требований высшей школы» (см. «Практические предложения, стр. 1) - Товарищи, запаситесь сперва основательными знаниями по методике предмета, и тогда ваша критика будет иметь вес и значение. В настоящее время, высказанная невежественно, она только вызывает пожимание плечами.

В заключение нельзя не обратить внимание на кажущуюся даже и на первых порах подозрительной, - ту мелочную придирчивость, которая проявлена обследованием по поводу программ. Впрочем, такая тенденция проходит красной нитью через все материалы обследования.

Заканчивая обзор наших учебных планов и программ, должно сказать вообще, что всесторонняя выработка их по целому циклу на- 
учных дисциплин в связи с целеустановками данного ВУЗ`а дело не одного года. Так напр. в ленинградском институте философии, истории и литературы, образованном на выделенном из состава ленинградского университета ист.-филолог. факультета в 1930 г., «только к 1935 г. могли дать четко разработанные учебные планы и программы, над составлением которых на самом деле проделали большую и сложную работы. Они окончательно отработаны и приготовлены к изданию, в порядке обзора преподавания по основным курсам, читаемым на факультетах института. Последние два года дали возможность испытать и проверить как их научные, так и педагогические установки...» (См. Университеты и научн. учреждения, стр. 238).

Добавим, что устойчивости наших учебных планов и программ препятствовали многие обстоятельства, о которых мы, при случае, поговорим.

II.

После вышеприведенных объяснений относительно наших учебных планов и программ необходимо относиться к рассмотрению общих установок тех данных, которые изложены в 2-10 главах «материалов».

Прежде всего бросается в глаза тот факт, как уже выше отмечалось, что обследование не вполне использовало материалы по кафедре, главным образом основываясь на голословных показаниях студенческих представителей, которые почти никогда не посещали заседаний кафедры, и потому вполне естественно, что они по касающимся ее вопросам отличаются полной неосведомленностью. Так напр. на стр. 13 раздел 9-й: «...С дипломантами прошлого выпуска кафедра не вела никакой систематической работы и потому не могла бы отвечать и за качество работ их...»

Что касается дипломантов прошлого выпуска, то, хотя и студенческие представители утверждают, что кафедра не вела никакой систематической работы, но если бы обследование обратилось к письменному материалу по этому предмету, то оно, может быть, пришло бы к другим выводам. По представлению зав. кафедрой кит. яз. в июне 35 г. в деканат ВОСфака данных относительно консультаций дипломантов можно судить, что мною, в порядке руководительства их занятиями были проведены консультации по разработке китайских журнальных статей для дипломных заданий: с Арсеевым - 17 1/2 часов, с Сидихменовым - 10 1/2 часов, в течение которых мною объяснялись непонятные им места текста, причем, по <стр. 4> моему требованию, они давали мне устный перевод всех статей, от начала до конца. Т. Медовая, проживавшая постоянно в Хабаровске, [была] у меня на консультации два раза: один раз в то время, когда она перевела одну из дипломных статей, и второй раз, перед защитой дипломной работы она консультировалась относительно «тезисов». Кроме того, по дипломным работам консультировались Волченкова - 6 час., Дубовова - 8 час., Житкова - 8 час., Израилева - 6 час. еще в январе 1 ч. 50 мин.), Миндалевич - 2 часа, Фролова - 4 часа, а всего - 62 часа 50 мин. (не счита часов т. Медовой). Разница между фактическим положением дела и показанием студенческих представителей - огромна. 
Кафедра, конечно, не может входить в рассмотрение причин, почему некоторые консультировавшиеся лица прекратили посещения, и закладывают на неопределенное время сдачу своих дипломов.

Естественно возникает вопрос: каков же удельный вес голословных показаний студ. представителей т. т. Потапова и Денищенко - и вообще, и по некоторым другим вопросам - в частности. Разберем заявления их относительно «зубрежки», самостоятельной проработки, относительно лекций по истории китайской литературы и проч.

Подходя к первому вопросу можно уже априорно сказать, что такой нелепости, как «вызубривание перевода, для чего он будто бы диктуется» не допустит ни один преподаватель высшей школы. Не трудно понять всю дикость такого довода, если постараться, sine ira et studio, вникнуть в условия постановки изучения у нас китайского литературного языка, для чего мы принуждены сделать довольно большое отступление.

Преподаваемый на двух последних курсах: III и IV (вместо 2 1², 3, и даже 4-х годов его изучения в других научных учреждениях), раздробленный притом на несколько почти самостоятельных дисциплин (классический язык, оффициальный язык, газетный стиль), - этот строго выдержанный литературный стиль, даже в Китае, на первых ступенях своего изучения среди китайцев, неизмеримо лучше, чем наши студенты, подготовленных к восприятию этой дисциплины, проходится под непосредственным постоянным и всесторонним наблюдением преподавателей для надлежащего усвоения лексического и идиоматического материала. Речь о самостоятельной проработке начинается по окончательном усвоении элементарных начал этой науки, - начал, требующих большого труда преодоления их, во всяком случае не год и не два. У нас, на четвертом курсе, т. е. На втором и последнем году изучения литературного языка (стиль байхуа в этот счет не идет) необходимо ознакомить слушателей с передовыми статьями больших китайских газет в литературно-классическом стиле. Для иностранца - не китайца, изучавшего этот язык один только год, такая передовая газетная статья должна представлять не малые трудности для понимания. Надо научиться еще тому, как подойти к тексту, как производить грамматический разбор его, надо уяснять значения служебных слов, которые бывают весьма разнообразны, надо научиться разбираться в дяньгу, и - самое главное - переводить на другой язык. В этом заключается коренная задача преподавателя научить всем этим языковым элементам слушателя (слушателя среднего уровня), элементарному подходу к тексту, а затем и к переводу. Получаемый таким образом от преподавателя материал студент должен прорабатывать самостоятельно дома, и тут, на основании полученных разъяснений, представляется полная возможность вникнуть в текст и осмыслить его перевод.

Чтобы рельефнее дать понять всю трудность штудирования газетных передовых статей на кит. яз., - такого предмета, которого нельзя выкинуть из наших программ, - приедем аналогию. На втором году изучения английского языка возможно ли самостоятельное чтение студентами передовиц больших английских газет? Ответ конечно получится отрицательный. Но при прохождении английского языка студенты имеют еще третий и четвертый годы, которые выправят все их недочеты. Изучение у нас кит. лит. яз. (имеющего такое же отношение 
<стр. 5> к современному мандаринскому и другим диалектам Китая, как древний латинский к современным: английскому, французскому, итальянскому, испанскому и румынскому языкам) требует, независимо от изучения современного разг. яз., еще особого специального изучения, которое вряд ли возможно начинать лишь с третьего курса. (Наримановский институт начинает его со второго семестра II курса.)

В таком же, если еще не более усложненном положении находится у нас изучение классического языка. Китайский классический текст, создававшийся две тысячи с лишком лет тому назад, но имеющий определенное влияние на современный язык, в течение такого долгого времени уже начинал нуждаться в объяснениях своих текстов. К нашему времени появилось значительное число комментариев на текст, из которых некоторые, признанные ортодоксальными, считаются обязательными при изучении языка классиков, остающихся, без этих объяснений, темными. В чем должна заключаться задача самостоятельной проработки текста? Очевидно в том, чтобы самостоятельно было определено значение каждого слова и выяснен хотя бы общий смысл каждой сентенции. Это почти недостижимо в начале второго года изучения языка, так-как приходится иметь дело со специфическим языком комментаторов. Но к этой работе студенты не обращаются. Есть еще и другой метод, это работа по английскому переводу, но сами студенты сознавались в трудности для них такой работы. Естественно, что изучение классического языка нужно вести путем моего личного интерпретирования курса согласно тому смыслу, который дают комментаторы в свете тех научных достижений, которые дает китайская и европейская наука.

Таков предмет, подлежащий нашему изучению. Если перечисленные разнообразные стили языка чрезвычайно богаты иероглификой, прочной связью с архаическими и древними наречиями Китая, идиоматизмами, то они не менее отличаются богатством особенностей синтаксических построений языка, делающих китайскую грамматику литературного языка одною из сложнейших в мире. В рукописи грамматика кит. классического языка занимает свыше 500 стр. Один практический словарь служебных слов, заключающий в себе учение только о 26 служебных словах, охватывает 135 страниц.

На восфаке преподавание восточных языков, в том числе китайского, носит свой специфический характер. На старших курсах, III и IV-м, при практическом изучении литературного языка, - статьях из кит. газет и журналов, избранных глав из классических произведений и проч., - необходима постоянная интерпретация текста со стороны научного работника. Те каждые два часа, отводимые на тот или другой день по расписанию, не является простой «проработкой» текста, как стараются доказать студенческие представители. В такое штудирование восточного текста входят элементы: 1) лекционный, т. е. объяснение текста преподавателем со стороны его грамматики, фонетики, семасиологии и истории языка (где даются им сведения, составляющие квинтэссенцию современного состояния данной науки во всей многогранности ее научных положений, - сведения, которых, помимо аудитории - не найдут ни в каких пособиях), и 2) элемент практический, - когда преподаватель вводит контрольный метод для того, чтобы убедиться насколько текст с привходящими в него грамматическими и другими моментами усвоен слушателями. Таким об- 
разом, естественно создается такое положение, при котором лекционный и практический (семинарский) элементы дополняют друг друга, находясь во взаимном гармоническом сочетании. Ясно, что такая интерпретация текста основана на практическом методе его усвоения, так-как общенаучные лингвистические установки даются не только в виде теоретической первоосновы, но проводятся путем грамматического анализа живого материала, представляемого журналом, газетой или классиком. Конечно, на целом ряде тщательно подобранных текстов, разбираемых таким методом, в течение академического года <стр. 6> перед слушателями проходят основные элементы литературной речи, и такой годовой курс, ведомый соответственным научным работником, представляя плановое осуществление выдвинутой перед ним задачи, разрешение целого ряда грамматических проблем, имеет не меньшее значение в учебном режиме, чем напр. читаемые соответствующими преподавателями лекции по химии, физиологии, анатомии и проч.

Разница в преподавании восточных языков на нашем восфаке - с одной стороны, и - преподавания наук на других факультетах с другой, та, что каждые два часа по китайскому языку, как уже было сказано выше, заключают в себе два элемента: лекционный и семинарский, тогда как при другой системе преподавания, в зависимости от присущего той или другой дисциплине преподавания, требуемой спецификой ее, лекционная и семинарская части ведутся особо.

Для примера того, как ведется преподавание - помимо того, что уже говорилось мною по этому предмету в объяснительной записке по поводу статьи: «мы не школьники», приведем несколько фактов.

При интерпретации текстов делаются ссылки на фонетику китайского языка. Напр., была прочитана лекция о природе 5-го входящего тона (жу-шэн), об особенностях его произношения в древней и средневековой литературах, о причинах его исчезновения на севере Китая и существования его в южных наречиях в настоящее время.

Давались обстоятельные сведения о физиологии звуков кит. яз., об артикуляционной базе, и о различии ее от таковой русского языка. Это был переход из области семинара в область лекции на фоне общих языковых научных положений интерпретации текста.

При штудировании текстов из классической книге луньюй (афоризмы Конфуция) такой характер преподавания развёртывается еще шире. Он характеризуется сообщениями, лекционным путем, необходимых для понимания текста фактов из истории Китая, его бытовой и культурной жизни, его просвещения. И все это делается на фоне лингвистических и других установок текста, как их дают китайские комментаторы, причем, помимо общепризнанного авторитета Чжуси мы обращаемся и к более древним комментаторам. Можно ли назвать такое преподавание классического языка простой «проработкой» и может ли быть оно заменено некомпетентной студенческой самостоятельной проработкой? Ни в коем случае - нет.

Для активизации проработки материала студентами нами установлен особый педагогический подход. Именно для этой цели предлагаются, в порядке прохождения курса, соответственные статьи из практического словаря служебных слов. Это пособие, составленное на основе научных синтаксических построений, - помимо того, что обстоятельно знакомит с новейшими научными достижениями в об- 
ласти китайской грамматики на основе глубокого анализа образцов письменного языка, - вводит еще в общую идеологию синтаксиса вообще. Предлагая слушателям самостоятельную работу по внеклассному штудированию предмета, я имел в виду достижение двоякой цели: привитие учащимся приемов аналитического метода при разборе текстов, как дополнение к той интерпретации их, которая ведется на лекциях, а затем и приобретение навыков к самостоятельному мышлению в плоскости осознания явлений чуждого языка. Как фактически осуществлялась самостоятельная проработка, - об этом я уже сообщал в своем ответе относительно газетной стать т. Потапова.

Из всего вышеизложенного ясно, что постановка преподавания предмета совершенно отвечает задачам высшей школы, и усвоение дисциплины по нашим методам требует, чтобы умственное развитие учащихся было на высоте уровня высшей школы. Анализ языка китайского текста, основывающийся на таких научных дисциплинах, как фонетика, синтаксис, морфология и семасиология, представляет сложную умственную работу познавательного свойства с напряжением волевых центров, что под силу только достаточно развитым умам. Разъясненный во всех подробностях перевод, как и математическая теорема или задача, не заключают в себе таких элементов сильного напряжения памяти, как например запоминание целого ряда химических формул или хронологических $<$ стр. 7> таблиц. И только в тех случаях, когда умственное развитие учащегося не находится на высоте уровня высшей школы, он старается злоупотреблять памятью, если соображение отказывается ему служить. Зубрят теоремы, зубрят переводы только тупицы, только люди с весьма ограниченным развитием, и чрезвычайно прискорбный факт, что учащиеся этой категории, принижая до своего убогого уровня мышления богатые научным содержанием университетские дисциплины, которых они все равно охватить не в состоянии, бросают камень в преподавателя. Китайский философ Мэнцзы говорит, что «лягушка, сидящая на дне колодца, думает, что небо представляет из себя ничтожный кружок. Не небо мало, узок ее умственный кругозор». В параллель этому сравнению нужно сказать, что не постановка дела преподавания языка узка (имеются ведь и другие отзывы о нашем преподавании от хорошо учившихся когда[-то?] у нас способных и развитых в умственном отношении лиц), а безнадежно узки те взгляды, которые все свое недопонимание предмета, всю свою «нелепую зубрежку» сваливают на методический актив кафедры.

Положение становится еще более сериозным, если обратим внимание на отсутствие у большинства особого интереса к языкам. К 1 янв. сего года было неуд. (2) на III к. - $11 \%$, на IV к. - 14\%; уд. (3) на III курсе - 44\%, на IV курсе - 54\%, на V к. - 74\%, что лучше всего иллюстрирует приведенное нами положение. Несомненно в общем режиме социалистического строительства мы имеем такие важные факторы подъема учебы, как ударничество и соцсоревнование, которые должны развиваться среди учащихся, при обязательстве для каждого учащегося. Перед учащимися стоит еще один новый фактор, это - проведение стахановских темпов проработки учебных заданий на прочно оборудованной технической базе. Эта очередная задача [неразборчиво] стоит перед нашим студенчеством, и от него мы ждем ее разрешения. Все это говорит в пользу того, что прежние 
нормы оценки успеваемости становятся уже оценками вчерашнего дня, не соответствуя настоящему моменту, и нам необходимо перейти на более повышенные нормы оценок, что явится побудительным стимулом, а в некоторых случаях подталкивающим средством проведения в жизнь элементов социалистической строки работы. Мы знаем, что наша оценка 3 (уд.) считается достаточной для перевода на след. курс. Но это - по нашему мнению - недоразумение. Когда ставится 3 ? Когда ответом обнаружено знание приблизительно на $3 / 4$ из заданного вопроса. Следовательно $1 / 4$ данного вопроса относится к незнанию. Сколько же получится этих недостающих четвертей за целый год и сколько их накопится за все четыре года у безнадежно хронических троечников?. Какие отрезки невосполненных знаний, накопившиеся к IV курсу, а вместе с этим какие пробелы появятся в общей экономии специального знания языка, создающие искаженное представление о данной научной дисциплине и о методах ее усвоения? Неудивительно, что на производственном совещании IV курса заговорили о понижении требований по курсу кит. яз., маскируя это положение громким лозунгом: давать материал дифференцированно по силам. Какие же могут быть силы у студентов нисшей категории и не придется ли безнадежно толочься на месте на текстах легкости II и пожалуй III курса? Как понизить общую стандартную трудность требуемых учебными планами газетных статей на вэньли, и как студент будет сам справляться с чрезвычайно сложной грамматикой литературного языка, и не придется ли преподавателю специально читать каждому студенту отдельно лекцию о том или другом служебном слове, вместо того, чтобы прочитать ее сразу всем? Учтен ли студентами большой объем IV курса, при котором работа отдельно с каждым студентом и повторение одного и того же, может быть, 14 раз сильно замедлит темпы прохождения курса при отсутствии гарантии усиления их?

Перед нами стоит настоятельное требование введения и укрепления методов активизации прохождения учебного материала. С лучшими студентами решение этой задачи не встречает затруднений, если только они не будут хватать через край. Сложнее дело обстоит со средними и плохими студентами. Вся активизация их работы в большинстве случаев сводится к набиранию иероглифов по словарю с большой затратой времени. <стр. 8> Теперешний V курс являет ясное тому доказательство. С переводом они самостоятельно не справлялись. В введении и укреплении методов активизации отнюдь не должно мыслится сведение на нет активной роли преподавателя-интерпретатора, являющегося на лекции выразителем основных принципов своей науки, основанных на тех или иных методах ее прохождения. Большой ошибкой [было бы] считать, что активная самостоятельная проработка текстов для каждого студента отдельно должна низвести роль преподавателя до роли корректора-переводчика текстов с низведением его роли выразителя своей научной индивидуальности до уровня простого консультанта. В предложении «общие статьи не прорабатывать» виден уродливый перегиб именно в эту сторону (прошу вспомнить, что было сказано выше о лекциях и семинарах на кит. отделении). Еще раз напомним о рациональной постановке у нас на китайском отделении объяснений и комментирования общих стандартных текстов, обязательных для всей группы, по систематическому подбору которых проводится сумма необходимых 
положений данной науки, и трудности которых сглажены подобными объяснениями. Поэтому интерпретация текстов ни в коем случае не может быть аннулирована без опасности потрясения основ нашего учебного процесса.

Этим однако ни в коей мере не уничтожаются возможности активной самостоятельной проработки предмета. К этой категории занятий мы относили и относим: 1) активную работу над синтаксисом кит. яз. (аналогия: активизация по химии, физике и др. науках при лекциях по этим предметам со стороны преподавателей), и 2) самостоятельную работу над текстами по словарям и другим пособиям индивидуально.

Перейдем к курсу китайской литературы. По учебному плану для V курса кит. отд. Восфака на 35/36 г. (27/IX 35 г.) было намечено «Введение в изучение китайской литературы» по след. программе: «Введение в изучение истории литературы. Два основных стиля современной китайской литературы: вэньли или литературно-классический и байхуа - литературно-разговорный в их исторических перспективах эволюции китайского языка. Отражение архаического китайского языка на памятниках древнейшей литературы. Литературный язык ханьской эпохи и влияние на него живой разговорной речи того времени, особенно на его грамматику. Язык и литература так наз. шести династий. Реформа языка при Танской династии. Возникновение народной словесности на байхуа при Сунской династии. Литература на байхуа при Юань. Борьба между стилями вэньли и байхуа и победа первого при Мин и Цин. Борьба за стиль байхуа при республике. Выдающиеся поборники этого стиля в настоящее время. Абрис новейшей литературы на разговорном языке. Параллельное течение, создаваемое стилем вэньли в современной литературе.

Семинарий по изучению литературы. Лучшие образцы в китайской литературе, относящиеся к эти двум стилям. Практическое ознакомление с особенностями этих двух стилей по избранным текстам».

Следуя этой программе, при учете ограниченного количества времени и возможностей, указанных выше, мы должны были сосредоточить наше внимание на двух основных моментах развития языка в контакте с сознанием народа, с тем сознанием, как оно вылилось в литературе. Что касается вопросов, затрагивающих социальные сдвиги в Китае, то конечно они должны быть знакомы слушателям из лекции по истории Китая. Если студенты отчетливо представляют (из того же курса) характер социально-экономических эпох, то они могут самостоятельно сделать выводы, при каких условиях происходило возникновение и развитие классической литературы, и понимать основные стимулы лит. революции.

Таким образом, программой были намечены два момента в истории китайской литературы: классическая литература и литература на байхуа.

Основой классического языка является классическая литература, - <стр. 9> ее текстуальная часть. Поэтому сделано подобное обозрение классических книг, их внутреннее содержание по главам языкового материала, и в особенности отмечался архаический стиль языка, приводились из шицзина отдельные пиесы в древней языко- 
вой передаче - как важный материал для исторической фонетики кит. яз. при научно-исследовательской работе в области изучения языка древних текстов. При обзоре, напр. цзочжуани, указывалось на историческое значение этого труда, на влияние его языка на на язык китайской исторической литературы вплоть до настоящего времени. Подчеркивалась связь современного литературного языка с древней литературой во всем ее объеме (классики, философия, история и смесь). При этом давались общие сведения по штудированию языка классиков известными синологами и об их трудах.

Сообщение сведений о языке «байхуа» я начал с «литературной революции». В основу изложения была положена статья «бишан Ляньшань», помещенная в январском выпуске 35 года журнала Дунфан цзачжи, составленная профессором бэйпинского университета Ху Ши. Последний является инициатором так наз. «литературной революции» в Китае. Он - выдающийся знаток китайского языка и литературы, и указанная выше статья является одною из блестящих страниц китайской литературы. В этом труде находятся данные об общественном значении этого языка, языка нового, высказанные словами Ху Ши.

Уже из сделанного на лекции изложения кит. рев. Было видно о принадлежности Ху Ши у реформистским группам Пекинского университета, именно к слоям либеральной и радикальной буржуазии. Наконец, что касается стиля байхуа, то современный китайский язык, как сообщалось мною на лекциях по частной методике, это язык определенных ступеней развития, язык определенных исторических эпох классового общества. Современный разговорный китайский язык представляет язык нации как исторической категории определенной эпохи, эпохи буржуазного расслоения общества, эпохи капитализма. Этим объясняется и роль Ху Ши, и классовые прослойки в языке байxya.

Но все эти выводы из сообщенного материала могли бы сделать и сами слушатели V курса. Как воспользовался этим материалом студенческих представитель? Предоставим говорить ему самому. Он говорит: «...трактовка вопросов литературной революции буржуазными синологами предлагается студентам без каких нибудь критических замечаний, как истина в окончательной инстанции...» Откуда т. Денищенко взяла буржуазных синологов? Ху Ши об них нигде в приводимой статье не упоминает и на них совершенно не основывается. Я, со своей стороны, не ощущал необходимости обращаться к каким-либо сомнительным измышлениям европейцев о таком предмете, по которому я мог черпать живой материал из первоисточника на китайском языке.

Очевидно студ. представитель смешал два понятия: «синологи» и «Ху Ши». Чем объясняется такая нелепая ошибка? Объясняется она тем, что т. Денищенко не соблюдает формальных законов мысли, а потому ее мышление не приводит к достижению истины. Если бы она соблюдала, напр., закон тождества, по которому $\mathrm{A}=\mathrm{A}$, а Б=Б, т. е. что «синологи» суть «синологи», а «Ху Ши» есть «Ху Ши», то она не смешала бы одних с другими и не впала бы в такую грубую логическую ошибку. Мы здесь не намерены читать лекцию по логике, но если бы студенческий представитель был знаком и с другими логическими законами (закон противоречия, закон достаточного основания и проч.), 
то его выводы не страдали бы такой хаотичностью суждения (с чем, впрочем, мы уже знакомы по другим выступлениям т. Денищенко, например в роде «это не классический язык, а классическое недоразумение»). Приходится иногда указывать на неграмотность некоторых учащихся в орфографии, но теперь, при случае, еще более должно подчеркнуть факт, что на V курсе существуют молодые люди, еще не научившиеся мыслить логически, те молодые люди,, которые, заканчивая курс восфака, скоро могут вступит в кадры аспирантуры. При таких мыслительных средствах, каких результатов можно ожидать от их будущей научно-исследовательской работы?

<стр. 10> Продолжаем далее. Т. Феклин (стр. 6, 25 дек.) в своем обследовании говорит след.: «...исчерпывающие данные (это о мифических синологах что-ли? прим. мое) помещены нами выше..» Он продолжает: «...что для студентов несравненно было полезнее прослушать сжатый систематизированный курс китайской литературы с древнего периода».

Не поняв принципиальной основы нашего курса, т. Феклин прописывает свой рецепт не по прямому назначению. Мы выше отмечали, что мы имеем в виду лишь введение в курс кит. лит. на базе двух основных стилей китайского языка. Изучать литературу без того языка, на котором она написана, нельзя. Это - наше основное убеждение. Невозможно наконец развернуть полный курс литературы с чтением избранных образов ее на китайском языке при весьма ограниченном числе часов. Из сообщения сухого сжатого перечня вряд ли что нибудь вышло бы. Наши слушатели (Гурьев, Найдюкова, Желтоножко, Пинчук - а за ними Денищенко) все равно жаловались бы на то, что курс подавляет большим количеством собственных имен, хронологических дат, номенклатуры массы сочинений, ничего не говорящих, так сказать, ни уму ни сердцу, со всеми происходящими отсюда последствиями. Поэтому для ознакомления с фактическим материалом старой литературы мною был рекомендован труд проф. Джайлса на английском языке с критическим подходом к нему со стороны социально-экономической. Обследование говорит, что не дается указаний источников. Нет, указания делаются, только тут приходится наталкиваться на нежелание студентов иметь дело с ними, если они на английском языке.

Учитывая все эти обстоятельства, я старался дать ряд живых лекций о классических книгах со всеми относящимися к ним данными, а затем о лит. рев., где помимо трактовки данного вопроса даются краткие схематические данные по истории литературы, но в живой, увлекательной форме.

По современной литературе даны, почерпнутые из китайских источников, данные о современной поэзии, романе, театре, эсеистах и проч. в связи с эволюцией современного разговорного языка и сильным влиянием на нее европейской, и в том числе советской, литературы и европейских языков. Отмечалось левое направление писателей Лу Синя, Го Мо-жо, Мао Дуня, Бо Цзиня, причем было обращено внимание на пролетарский характер их произведений по содержанию. Относительно Лу Синя обращалось внимание слушателей на его биографию, помещенной в московской газете «Правда». Затронута была коммунистическая литература на китайском языке и в особенности перевод на китайский язык сочинений Ленина. 
Основной подход был главным образом со стороны языка.

В заключение, мы не можем признать правильность мнения обозревателя, что слушателей нужно знакомить с кит. лит. по отрывкам на русском языке. Такой прием был бы более полезен для средней школы при изучении русской литературы. Русские переводы с художественной обработкой языка перевода соответственно тексту подлинника, как напр. «Лисьи чары» акад. Алексеева представляют почти единичное явление в русской литературе. Если прибавить сюда некоторые переводы по конфуцианству Попова (о переводах В. П. Васильева мы не говорим), то получится почти все, чем мы можем располагать для этой цели. Гораздо научнее было бы знакомить слушателей вообще по отрывкам из лучших переводов первоклассных знатоков китайской литературы, не только на русском, но и на других иностранных языках. В крайнем случае, мы можем ограничиться одним, цитированным выше, курсом Джайлса, дающим на английском языке множество извлечений из лучших произведений китайских писателей.

Представляет особое значение, что при чтении курса китайской литературы, ознакомление с отрывками произведений лучших писателей в оригинале. Нигде как в восточных литературах, именно в художественной литературе (в стиле вэньли) не выступает как ярко «хроматизм» языка, создающий чисто восточную образность идиом и метафор, на которых основана характеристика действующих лиц, событий и мест. И если еще мы примем во внимание контакт языка с сознанием народа, то поймем <стр. 11> все громадное значение изучения литературы в неразрывной связи с ее языком. Этот принцип, недостаточно еще освоенный другими, мы закладываем в основу изучения литературы, стараясь довести до сознания слушателей его важность. Такую цель мы преследовали при штудировании некоторых пьес из шицзина, и сожалеем, что недостаток времени не позволил нам расширить рамки таких чтений, введением в них отрывков из других произведений.

Заканчивая обозрение вопроса о китайской литературе, мы ответим на некоторые другие второстепенные вопросы по затронутым выше различным пунктам. Нападки, делаемые «материалами» на нас не существенны, но они все-таки могут сбить с толка невнимательного читателя этих «материалов», и поэтому нельзя не дать разъяснений относительно них.

Обследование в одном месте говорит: «..никакого внимания не обращается на грамматический разбор...» (стр. 6, 25 дек.), а в другом месте» «...делается обстоятельный разбор синтаксического порядка с дословным переводом...» - несообразности, взаимно уничтожающие друг друга. Далее: «...проработка общих статей состоит по существу в подаче перевода самим профессором...» Но странно было бы требовать самостоятельного перевода луньюя или шицзина от студентов, когда «подача» смысла этих книг совершается нашими профессорами по традиции изучаемой нами школы того или другого классика. О больших газетных передовых статьях мы говорили выше. Нужно понять наконец, что изучение на протяжении лишь одного года таких обширных языковых дисциплин требует заложения прочного фундамента, заключающегося в твердом усвоении необходимого определенного комплекса знаний, не путем бесцельного блуждания 
по многотомным словарям без всяких определенных выводов, а на многократно проверенном педагогическом опыте определенной школы изучения языка. Далее там же говорится: «...нет дифференцированного подхода...» и т. д. Нет, наоборот, практикуется опрос студентов, причем делается ставка на более слабых (см. мой ответ на статью т. Потапова). Несколько выше: «...на 4-м курсе...» и т. д. Но относительно самостоятельной работы по грамматике и газ. стилю (вырезкам из газет) мы уже говорили выше. Чем объясняется индеферентное отношение студентов к этим вопросам? Но самостоятельная работа по газетным вырезкам велась студентами Тарасовым, Потаповым и отчасти Кимом. Что же делали другие? Постоянной опеки преподавателя над активной проработкой этих материалов не было. Тут предоставлялась возможность свободной самостоятельной работы и располагать временем и материалом по своему усмотрению. Причина заключается в том, что усвоение грамматики требует больших умственных усилий, след. эта дисциплина носит «ярко выраженный отрицательный характер», и осмысленное прохождение грамматики «не только не приучает студентов к самостоятельной работе, но, наоборот, заглушает проявление всякой самостоятельности в учебе». Еще приведем факты: В ноябре 35 года всему IV курсу были розданы вырезки из газет. Представили переводы только четыре студента. От остальных ничего не поступает до сих пор. На V курсе по референтскому уклону мною даны три темы для самостоятельной проработки Найдюковой, Назарову и Желтоножко, но они до сих пор не подают никаких признаков активности.

III.

Теперь должно обратиться к «Выводам по итогам обследования кафедры...», причем мы будем отмечать пункты, непосредственно касающиеся наших дисциплин.

\section{2. Отрицательные выводы.}

Раздел 1 п. 1 - Признается лишним на III и IV курсах, так-как делается упор на приобретение навыков по чтению журналов [неразборчиво] типа «дунфан цзачжи».

п. 2 - на основании всего изложенного видно, что не верно.

<стр. 12>

Раздел 2 п. 5 - База закладывается, но студенты недостаточно прилежны.

п. 6 - не верно.

п. 11 - по единичному случаю нельзя судить о том, как дело ведется в течение года. В общем весь вывод неверен.

Раздел 3 п. 2 - у студентов не наблюдается достаточно желания этому.

Раздел 6. п. 3 - причина лежит, во многих случаях, в самих студентах.

Раздел 9 - совершенно неверно. 
2 Документ № 9.
Раздел X

Раздел 12
- обследованию неизвестны задания по производственной практике. Еще см.: Червонецкий. К обследованию кафедры ${ }^{2}$, стр. 10.

Кафедра неоднократно вела собеседования со студентами по этому вопросу, но с их стороны не встречала отклика.

По поводу выводов студ. Потапова необходимо отметить след.:

1. Причины этого явления, за исключением Тарасова, Кима и Потапова, лежат в самих студентах.

2. Методологические вопросы именно стоят в центре работы кафедры, это можно судить по составляемым от поры до времени методическим запискам (см. наш обзор материалов по кафедре, помещенный выше). Потапов никогда не посещает заседаний кафедры, а потому об этой работе отличается полной неосведомленностью.

3. Объясняется невозможностью получать из Китая новый материал. По поводу учебника Отте дано объяснение в ответе на статью т. Потапова.

4. Со стороны деканата ведется работа в этом направлении, и от него зависит главная руководящая роль в этом деле.

По дисциплинам, читаемым доцентом т. Червонецким, находится обстоятельный ответ в записке его «К смотру кафедры...»³.

Приходя к окончательному заключению должно констатировать, что обследование кафедры китайского языка неудовлетворительно проведено по целому ряду - принятых и осуществляемых на кафедре - «стержневых положений советской методики преподавания». Т. Феклин не учел всей ошибочности, обманчивости и тенденциозности показаний свидетельского персонала в лице студенческих представителей. Обследование не познакомилось с целым рядом письменных документов, имевшихся в более полном комплекте, чем те, которые оно использовало, или же, наконец, не привлекло к делу еще некоторых других лиц, имевших то или другое отношение к кафедре, заменяя их теми лицами, которые не могли быть беспристрастны (Козлов).

В связи с этим, наверное, а местами искаженное до неузнаваемости, представление обследования о «ряде моментов в учебнопроизводственном процессе работы кафедры» указывает на то, что обследование не проведено с должной беспристрастностью и компетентностью, и по своим общим выводам ни в коем случае не отражает действительного положения кафедры китайского языка ни со стороны «стержневых положений советской методики преподавания», ни со стороны «ряда моментов в учебно-производственном процессе кафедры».

Исходя из этого заключения и принимая во внимание окончательные выводы члена кафедры доцента т. Червонецкого о работе обследовательской бригады, что «по существу она направлена к дезорганизации производства и след. как стоящая на грани вредительства, эта работа должна быть признана позорной»; находя подтверждение этому в стремлении бригады скрыть отрицательные стороны отношений 
к целому ряду факторов специального учебного и вообще академического свойства с понижением интенсивности академического процесса, - при стремлении перенести центр тяжести обвинений с себя на кафедру; - последняя, не имея гарантии в том, что подобные факты не будут повторяться в будущем, и усматривая в этом элементы возможного разложения, поддерживает предложение т. Червонецкого о возбуждении перед дирекцией ходатайства о «полном и всестороннем расследовании всех обстоятельств работы бригады т. Феклина, с последующей передачей результатов расследования <стр. 13> на суд общественного мнения Университета».

На основании нашего «критического обзора» мы приходим к следующим выводам относительно развертывания производственного процесса нашей кафедры.

1. Усиление активизации самодеятельной работы студентов применительно к положениям, показанным нами на стр. 7 настоящего «обзора», согласно основным принципам нашего педагогического процесса, намеченным там-же.

2. Усиление методов социалистического строительства, заключающихся в ударничестве и соцсоревновании, при незамедлительном проведении в жизнь стахановских методов проработки учебных заданий.

3. Использование консультационных часов с неуспевающими студентами, в обязательном порядке их посещения, для более углубленной проработки нечетко усвоенного материала.

4. Дифференцируя силы и способности учащихся, освобождать наиболее успевающих студентов от присутствия на таких консультациях, с поручением им специальных заданий по языку для активизации их работы и придания ей большей самостоятельности.

5. Усилить связь теории с практикой в плоскости обязательной работы всех студентов на практических занятиях т. Чжана с безоговорочным выполнением его заданий по языку в порядке их активной самодеятельной проработки. Помимо этого, усиленно рекомендовать студентам вступать в контакт с националами учащимися других учебных учреждений Владивостока, и по примеру Ленинградского института истории, философии и лингвистики, развернувшего широкую сеть разговорных клубов (английский, немецкий, французский, японский, таджикский и проч.), разговорный русско-китайский клуб для учащихся двух этих национальных категорий.

6. В видах расширения изучения китайского литературного языка ввести его преподавание со 2-й половины II курса.

7. Войти с ходатайством в высшие инстанции о предоставлении Boc. фак. 'у бесперебойного получения книг на кит. яз. из Китая, для наилучшего и более полного ознакомления с современной литературой на китайском языке и своевременного снабжения учащихся более новыми пособиями.

Проф. А. Рудаков 9 февраля 1936 г.

РГИА ДВ Ф. Р-289. Оп. 1. Д. 291. Л. 19-26. 


\section{Materials of the Inspection of the Chinese Language Department of Far East State University, December 1935 - January 1936. Part 3}

DOI https://doi.org/10.24866/2542-1611/2021-3/137-154

Publication is prepared by Yaroslav A. BARBENKO,

$\mathrm{Ph}$. D. (in History), Associate Professor, Department of Political Sciences, Oriental Institute - School of Regional and International Studies, Far Eastern Federal University (Vladivostok, Russia).

E-mail: prohist@ya.ru

For citation: Materials of the Inspection of the Chinese Language Department of Far East State University, December 1935 - January 1936. Part 3 // Oriental Institute Journal. 2021. № 3. P. 137-154. DOI https://doi. org/10.24866/2542-1611/2021-3/137-154 